\title{
A Multidimensional Approach to Social Support: The Questionnaire on the Frequency of and Satisfaction with Social Support (QFSSS)
}

\author{
Miguel A. García-Martín*, Isabel Hombrados-Mendieta and Luis Gómez-Jacinto
}

University of Malaga (Spain).

\begin{abstract}
Título: Una aproximación multidimensional al apoyo social: El Cuestionario de Frecuencia y Satisfacción con el Apoyo Social (CFSAS).

Resumen: El Cuestionario de Frecuencia y Satisfacción con el Apoyo Social (CFSAS) ha sido diseñado para evaluar la frecuencia y el grado de satisfacción con el apoyo social percibido procedente de diferentes fuentes en relación a tres tipo de apoyo: emocional, informacional e instrumental. En este estudio se comprueba la fiabilidad del cuestionario, así como su validez estructural y de criterio. Los datos fueron obtenidos de una muestra compuesta por 2042 españoles. Los resultados muestran una alta consistencia interna (rango de valores del Alpha de Cronbach entre .763 y .952). El análisis correlacional mostró relaciones positivas significativas entre el CFSAS y medidas de bienestar subjetivo y apoyo social percibido, así como relaciones negativas significativas con medidas de soledad (rango de valores de la $\mathrm{r}$ de Pearson entre .11 y .97). El análisis factorial confirmatorio, usando ecuaciones estructurales, sugiere una estructura interna compuesta por cuatro factores, que se corresponden con las fuentes de apoyo analizadas: pareja, familia, amigos y comunidad (rango de valores GFI entre .93 y .95 , CFI entre .95 y .98 , RMSEA entre .10 y .07). Estos resultados confirman la validez del CFSAS como una herramienta versátil adecuada para la valoración multidimensional del apoyo social.

Palabras clave: apoyo social percibido; relaciones interpersonales; valoración multidimensional; Análisis factorial confirmatorio; Ecuaciones estructurales; Propiedades psicométricas.
\end{abstract}

\section{Introduction}

Social support is one of the most studied constructs in community psychology. Lin, Simeone, Ensel, \& Kuo (1979) offered a broad definition of social support as: "support accessible to an individual through social ties to other individuals, groups, and the larger community" (p. 109). Specifically, perceived social support refers to an individual's belief that social support is available and that it provides what the individual considers necessary (Sarason, Sarason, \& Pierce, 1990). Gottlieb \& Bergen (2010) provided the following global definition: "The social resources that persons perceive to be available or that are actually provided to them by nonprofessionals in the context of both formal support groups and informal helping associations" (p. 512).

Many studies have analysed the impact of social support on aspects such as physical health (Chatzisarantis, Hagger, \& Smith, 2007; House, Landis, \& Umberson, 1988; Martos \& Pozo, 2011; Salovey, Rothman, Detweiler, \& Steward, 2000), mental health (Cohen \& Wills, 1985; Melling, \& HoughetPincham, 2011; Pons-Salvador, Cerezo \& Trenado, 2014; Rimé, Páez, Basabe, \& Martínez, 2010; Sherman, Skrzypek, Bell, Tatum, \& Paskett, 2011), psychological well-being

* Dirección para correspondencia [Correspondence address]

Miguel Ángel García-Martín. Department of Social Psychology, Social Work, Social Anthropology, and East Asian Studies. Faculty of Psychology. University of Malaga. Campus of Teatinos S/N. 29071 Malaga (Spain). E-mail: magarcia@uma.es

\begin{abstract}
The Questionnaire on the Frequency of and Satisfaction with Social Support (QFSSS) was designed to assess the frequency of and the degree of satisfaction with perceived social support received from different sources in relation to three types of support: emotional, informational, and instrumental. This study tested the reliability of the questionnaire scores and its criterion and structural validity. The data were drawn from survey interviews of 2042 Spanish people. The results show high internal consistency (values of Cronbach's alpha ranged from .763 to .952). The correlational analysis showed significant positive associations between QFSSS scores and measures of subjective well-being and perceived social support, as well as significant negative associations with measures of loneliness (values of Pearson's r correlation ranged from .11 to .97). Confirmatory factor analysis using structural equation modelling verified an internal 4-factor structure that corresponds to the sources of support analysed: partner, family, friends, and community (values ranged from .93 to .95 for the Goodness of Fit Index (GFI); from .95 to .98 for the Comparative Fit Index (CFI); and from .10 to .07 for the Root Mean Square Error of Approximation (RMSEA)). These results confirm the validity of the QFSSS as a versatile tool which is suitable for the multidimensional assessment of social support.
\end{abstract}

Key words: perceived social support; interpersonal relationships; multidimensional assessment; confirmatory factor analysis; SEM; psychometric properties.

(Ownsworth, Henderson, \& Chambers, 2010; Blair \& Holmberg, 2008; Taylor \& Brown, 1988), and quality of life (Newsom \& Schulz, 1996, Song et al., 2011). However, the measurement of the construct remains an issue that has been addressed from different perspectives by many researchers using different evaluation instruments (Brown, Tang, \& Hollman, 2014; Hlebec \& Kogovšek, 2013; Gilbert \& Rhodes, 2012; Shakespeare-Finch \& Obst, 2011; UmañaTaylor et al., 2011). There are two basic perspectives on the construct: structural and functional (Barrera, 1981; Gottlieb, 1983). Although less important, the contextual perspective could be considered another approach.

The structural perspective addresses the objective characteristics of the social support network, such as its size, the number of members, the density of the relationships between members, or interconnections between possible subnetworks or domains (Lin, 1986). This perspective attempts to obtain quantitative information on the potential availability of support, rather than information on the subjective perceptions of the person receiving support.

In contrast, the functional perspective address the type of support received. House (1981) describes four fundamental types of support: emotional (e.g., affection, empathy, love, trust, care); instrumental (e.g., help in the form of money or equivalent, time invested, in-kind assistance, and other explicit interventions on the person's behalf); informational (advice, suggestions, or guidance to help the person deal with personal or circumstantial challenges); and appraisal (the 
provision of information in the form of social comparison or evaluative feedback to the receiver of support). The contextual perspective addresses the specific settings or networks in which social support is given or received. Tardy (1985) analysed social support measures and identified six different settings or potential sources of support: family, close friends, neighbours, coworkers, the community, and professionals. In an attempt to organize the variety of definitions of social support presented in the literature and to avoid the use of a single global definition, Tardy divided the concept of social support into five theoretical and operational dimensions. In addition to the network dimension, he identified a functional dimension related to contents (or types of support) and included a description/evaluation dimension, which addresses the objective aspects of support and satisfaction with support. The potential or actual provision of social support to which people have access represents another dimension of analysis that could be added to those mentioned. In line with Tardy's proposals, the analysis of social support could include its direction, that is, whether it is given or received. These two dimensions complement those proposed by House \& Khan (1985).

A review of the literature shows that the different definitions and operationalizations of the concept of social support have addressed some of the dimensions described above. For example, some authors have analysed received social support and its evaluation by the receiver, whereas others have addressed social support from sources such as the family or close friends (Lyons, Perrota, \& Hancher-Kvam, 2010; Vangelisti, 2009; Zimet, Dahlem, Zimet, \& Farley, 2010).

Many measures of social support have addressed these different aspects, as shown by the wealth of literature published in recent decades (Cohen, Underwood \& Gottlieb, 2001; Gottlieb \& Bergen, 2010; O’Reailly, 1988; Perrin \& McDermott, 1997; Tardy, 1985; Terol et al., 2004; Vaux, 1988, 1992).

A comprehensive review and classification of assessment tools of social support suggested that few measures have undergone extensive psychometric analyses and that many of these measures have been chosen on practical grounds rather than theoretical or psychometric grounds (Terol et al., 2004). The multidimensionality of the construct of social support and the distinction between structural and functional aspects have contributed to the diversity of instruments available and the incomplete assessment of social support. For example, although the widely used DUKE-UNC Functional Social Support Questionnaire (Broadhead, Gehlbach, DeGruy, \& Kaplan, 1988) assesses satisfaction with support received, it does not identify the sources of support, and only differentiates between confidential support and emotional support as the types of support received. Similarly, the Medical Outcomes Study - Social Support Survey (MOS-SSS) (Sherbourne \& Stewart, 1991) identifies four types of support (emotional/informational, instrumental, affectionate, and positive interaction), but only differentiates between the family network and the extrafamilial network as sources of sup- port. However, its factor structure was not confirmed when validated in a Spanish population in primary care (de la Revilla, Luna, Bailón, \& Medina, 2005). Given these shortcomings regarding the sources of social support, although the Arizona Social Support Interview Schedule (ASSIS) (Barrera, 1980) provides measures on the size and composition of the social network, it does not provide measures on the frequency of perceived social support from potential sources of support. A review of 262 published empirical studies also confirmed the existence of similar methodological problems in the measurement of social support and suggested that many of these studies evaluated social support using instruments that measured the construct in general non-specific terms without the support of an operational definition of the construct (Winemiller, Mitchell, Sutliff, \& Cline, 1993). Gottlieb and Bergen (2010) investigated various measures of social support and also highlighted the lack of attention paid to the multidimensional nature of the social support concept in relation to some of the specific instruments used in the evaluation of this variable.

The need to obtain a measure of social support that addresses one or more of the dimensions mentioned and the attempt to adapt the instrument to a specific study population has led the majority of researchers to construct measures that fit their specific purposes, but that may not be completely reliable or validated (Gottlieb \& Bergen, 2010). A review of the literature shows that there are many studies on the application or validation of some of these instruments in populations and settings whose characteristics make the results difficult to generalize (Ayala et al., 2012; Bordes, Sand, Arredondo, Robinson, \& Dixon, 2006; Cuellar-Flores, \& Dresch, 2012; Ekbäck, Benzein, Lindberg, \& Årestedt, 2013; Holden, Lee, Jockey, Ware, \& Dobson, 2014; López et al., 2007; Mas, Amador, Gómez, \& Lalucat, 2013; Rivas-Díez, 2013)

Instruments are needed that can provide systematic measurements of the most characteristic aspects of social support and that can be adapted to specific study populations. These characteristics are the type of social support, the frequency of social support, and satisfaction with perceived support. Different measures of these three dimensions are also needed in relation to the potential sources of social support. Although some instruments have been developed to assess social support from a multidimensional perspective, many have failed to fully incorporate this perspective into their design. For example, the 12 items of the Multidimensional Scale of Perceived Social Support (MSPSS) (Zimet et al., 2010) do not distinguish between different types of perceived social support according to the sources that provide it. The three sources are family, friends, and significant others. The Manheim Interview on Social Support (Veiel, 1987) was another attempt to measure social support from a multidimensional perspective. However, similar to the MSPSS, it does not provide a detailed measure of satisfaction for each of the types of support received. It establishes four potential sources of support (family, friends, neighbours, and oth- 
ers), which closes off the possibility of analysing other possible sources that may be of interest to the evaluator.

The MOS-SSS (Sherbourne \& Stewart, 1991) evaluates structural and functional support using a self-administered questionnaire composed of 20 items. The first item addresses the number of close friends or close relatives the participant has. The remaining 19 items address the frequency of support related to specific aspects of everyday life. This scale does not assess satisfaction with the social support received, support from several sources, the various types of support provided by these sources, or satisfaction with each type of support.

The Social Support Questionnaire (SSQ) (Sarason, Levine, Basham, \& Sarason, 1983) differentiates between the availability or frequency of perceived social support and satisfaction with such support. However, this instrument only measures emotional support (29 items) and instrumental support (15 items), but does not identify sources of support or the type of support provided by them. The same limitation is present in widely used instruments such as the Arizona Social Support Interview Scale (Barrera, 1980), the Perceived Social Support from Family and Friends (PSS-Fa and PSS-Fr) (Procidano, 1983), the Interpersonal Support Evaluation List (Cohen \& Hoberman, 1983), or the Lubben Social Network Scale (Lubben, 1988).

Although the psychological literature is replete with instruments to assess perceived social support, the majority of these instruments only provide partial measurements, and only address aspects concerning its origin, the type of social support, and the frequency of and satisfaction with such support. Terol et al. (2004) reviewed the psychometric properties of more than 20 instruments used to assess social support. Their study showed that these instruments addressed a wide variety of aspects of social support and that each instrument had different psychometric properties. The practice of psychosocial intervention and research suggests that combined measures, as previously described, are the most effective means to assess the main aspects of social support. Given this background, and based on a functional and contextual approach to the concept of social support, the QFSSS was designed to assess the frequency of support received from the support network (partners, family, friends, and community), and the degree of satisfaction with the support received from this network in relation to the three types of support (emotional, instrumental and informational) (see Appendix). The structure of the QFSSS enables its adaptation to the support networks being evaluated. Thus, other networks can be added to the four networks or the number of networks can be reduced. For example, a hypothetical study may wish to include the coworker support network, whereas a different study may only seek to address the family support network (partners, children, parents, and siblings). The structure of the scale was designed to measure the individual's perception of social support received. However, the simplicity and parsimony of the scale means that it can be easily adapted to assess the same dimensions of the social support provided. These potential features of the scale are being addressed as part of ongoing research.

This study investigated the psychometric properties of the QFSSS when applied to a large sample of subjects and analysed a group of instruments used to calculate its internal consistency, underlying factor structure, and concurrent validity.

\section{Method}

\section{Participants}

A proportional allocation stratified sampling procedure was followed in which the Málaga City Population Census was used to establish representative quotas by sex and age. The age groups were: 15 to 25 years, 26 to 40 years, 41 to 64 years, 65 to 74 years, and more than 75 years. The sample consisted of 2042 residents of ten municipal districts of Malaga city (Spain). Random-route sampling is appropriate to this type of research and was therefore used to select the sample after determining the representative quota of the global sample based on social districts. Routes for each district were randomly selected from a map indicating streets, buildings, squares, houses, and so forth. The Census was used to obtain a representative sample from each district. Each interviewer interviewed a specific number of men and women of a given age range in each district. Although the initial the sample consisted of 2091 participants, 49 interviews were removed from the database due to non-completion of all the measures used in the study.

\section{Demographic characteristics}

Table 1 shows the demographic characteristics of the sample. The average age was 46.93 years $(S D=19.24$; range $15-83$ years). The distribution by sex was practically equal $($ men $=50.4 \%$, women $=49.6 \%)$.

\section{Procedure}

Data were collected from October 2012 to January 2013 by interviewing a sample of residents of ten districts of Malaga city. The interviews were conducted by psychology students who had received 3-hour training sessions in the administration of the questionnaires. Prior to the interviews, the participants were contacted by the interviewers, who provided proof of identity. The interviewers gave the participants an introductory letter that described the aim of the study and assured them of the confidentiality of all the information collected. All participants gave their verbal consent to participate in the study and an interview was arranged to take place in their homes. The interviewees were provided with the telephone number of a researcher who they could call if they needed more information. Each interviewer interviewed 17 people of a specific sex and age. Regarding the latter variables, the proportion of interviewees matched the 
demographic distribution of the population of the city of Malaga (INE, 2009). In addition to the variables associated with social support, loneliness, and subjective well-being, each interviewer collected information on the most relevant sociodemographic variables (including marital status, educational level, profession, age, and sex).

Table 1. Demographic Characteristics of the Sample.

\begin{tabular}{lc}
\hline Variable & $\%$ \\
\hline Age (years) $M=46.93 \quad S D=19.24$ & 12.8 \\
\hline 15 to 25 & 25.6 \\
26 to 40 & 37.1 \\
41 to 64 & 12.3 \\
65 to 74 & 12.2 \\
$\geq 75$ & \\
\hline Gender & 50.4 \\
\hline Male & 49.6 \\
Female & 28.1 \\
\hline Marital status & 51.5 \\
Single & 6.2 \\
Married & 5.5 \\
Partnered & 8.6 \\
Divorced/Separated & 24.1 \\
Widowed & 13.4 \\
\hline Education & 18.5 \\
Graduate degree & 26.9 \\
Currently in college & 17.1 \\
High school & 13.9 \\
Primary studies & 22.4 \\
Without any of the former studies & 38.9 \\
\hline Home situation & 24.7 \\
\hline Living alone & \\
Only with the partner & \\
With the partner and family & \\
With the family and no partner & \\
\hline
\end{tabular}

\section{Instruments}

Eudemon Scale of Personal Well-being (EBP) (Fierro \& Rando, 2007)

The EBP was originally designed in Spanish and comprises 24 items with an average score of 75.91 ( $\mathrm{SD}=12.69$, $\mathrm{N}=463$ ). Scores range between 24 (low personal well-being) and 96 (high personal well-being). The scale measures the degree of well-being recently experienced by people, where well-being is understood as "eudemonic" welfare (from the Greek "eudaimonia" meaning happiness) or personal fulfilment. The items that comprise the scale have good internal consistency (Cronbach's $\alpha=.92$ ). Responses are given on a 4-point Likert scale: Not at all/rarely/sometimes/totally true. The items address satisfaction or dissatisfaction with life as well as the positive and negative emotions experienced. Principal Component Analysis (PCA) shows two components: the absence of well-being $(\alpha=.91)$, measured by 17 items that address the negative affect experienced by the person (e.g., "Life seems rather sad"); and positive wellbeing $(\alpha=.79)$, measured by seven items that address self- reported positive affect (e.g., "I'm happy with what I do daily").

Questionnaire on the Frequency of and Satisfaction With Social Support (QFSSS): Spanish version (Hombrados-Mendieta, Gómez-Jacinto, Domínguez-Fuentes, García-Lieva y Castro-Travé, 2012)

This instrument was designed to assess the frequency of and the degree of satisfaction with social support. It measures these aspects in relation to the three types of social support most studied in the literature (emotional, instrumental, and informational support) received from four sources of social support (partner, family, friends, and community) (see Annex). Frequency of support is measured on a 5-point Likert scale: rarely/sometimes/quite often/almost always/always. The degree of satisfaction with support received is also measured on a 5-point Likert scale: unsatisfied/barely satisfied/ fairly satisfied/quite satisfied/very satisfied. The scores for both frequency of and satisfaction with each source of support range from 3 to 15. The total scores on the frequency of and satisfaction with the four sources and three types of support (total $=24$ items) range from 12 to 45 and from 4 to 20 , respectively.

Social and Emotional Loneliness Scale for Adults (SESLA-S): Spanish version (Yárnoz, 2008)

This instrument is the Spanish adaptation of the Social and Emotional Loneliness Scale for Adults (SELSA; DiTomasso \& Spinner, 1993), which was based on Weiss's (1973) multidimensional concept of loneliness. The original 37-item scale evaluates three types of loneliness: social loneliness, family loneliness, and romantic loneliness. Subsequently, DiTomasso, Brannen, \& Best (2004) created a 20-item version of the SELSA. The Spanish version (SESLA-S) consists of 15 items (e.g., "I feel lonely when I'm with my family"), which are scored on a 7 -point Likert scale ranging from 1 to 7 , representing strong disagreement and strong agreement, respectively (minimum score 15, maximum score 105). An exploratory analysis of variance was conducted using the principal components extraction method with varimax rotation. The PCA showed three components that accounted for $63.51 \%$ of the total variance: social isolation $(23.5 \%)$, family loneliness $(21.4 \%)$, and romantic loneliness $(18.5 \%)$. Convergent and discriminant construct validity were supported by the correlational analyses conducted with other theoretically relevant measures related to the construct loneliness, such as attachment style, social desirability, and psychological wellbeing. The correlations between the three components of the SESLA-S scale and each of these measures were significant in the predicted direction. The reliability of the total scores on the SESLA-S was better than acceptable (Cronbach's alpha coefficient; $\alpha=.84$ ). Although there was only a difference of 0.01 between Cronbach's alpha coefficient for the total scale scores and the family and romantic loneliness sub- 
scales scores $(\alpha=.83$ for both subscales), Cronbach's alpha coefficient for the social loneliness subscale scores was considerably lower $(\alpha=.71)$. Some of the internal consistency values were even higher (total scale scores: $\alpha=.86$; family loneliness scores: $\alpha=.83$; romantic loneliness scores: $\alpha=$ .86; social loneliness scores: $\alpha=.84$ ) (Yárnoz, 2008). These findings support the use of the SESLA-S as an effective measure to assess loneliness from a multidimensional approach and, given the aim of this study, its use as a criterion to validate the QFSSS.

The Medical Outcomes Study - Social Support Survey (MOSSSS): Spanish version (de la Revilla et al., 2005)

This questionnaire consists of 20 items and is based on the English version (Sherbourne \& Stewart, 1991). The first item addresses how many close friends and family the participant can rely on. The remaining 19 items are scored on a 5point Likert scale ranging from 1 (never) to 5 (always). The instrument assesses four types of functional social support: emotional/informational support (e.g., "Someone you can count on when you need to talk"); material/instrumental support" (e.g., "Someone to help you when you have to stay in bed"); affectionate support (e.g., "Someone who shows you love and affection"); and positive social interaction (e.g., "Someone you can have a good time with"). The scores on the Likert scale range from 19 and 95 points. The PCA applied to the Spanish version shows three components that explain $68.72 \%$ of the total variance (de la Revilla et al., 2005). The first component (emotional/informational) accounts for $29.97 \%$ of total variance, the second (emotional support) accounts for $20.49 \%$, and the third (instrumental support) accounts for $18.26 \%$. The internal consistency of the three components was high: emotional/informational $(\alpha$ $=.94)$, emotional support $(\alpha=.86)$ and instrumental support $(\alpha=.87)$.

\section{Data Analyses}

Descriptive and reliability tests were conducted to analyse the demographic characteristics of the sample and measure the internal consistency of the QFSSS. To test the criterion validity of the QFSSS, bivariate correlation analyses between all the study variables were conducted using Pearson's $r$ statistic. The SPSS version 18.0 software package was used for all statistical analyses. Confirmatory factor analyses were also applied to test the factor structures of the QFSSS using the PRELIS 2 and LISREL 8.30 software packages (Jöreskog \& Sörbom, 1993).

Following the recommendations of Brown (2006), the Unweighted Least Squares (ULS) estimation method was used. Confirmatory factor analysis was performed taking into account the structure and rationale of the questionnaire, which was structured according to information on the frequency of and perceived satisfaction with social support from the four potential sources mentioned above. The objec- tive and the functional structure of the instrument also justify the use of a confirmatory factor model according to the functional structure proposed by Tardy (1985), which was based on the types of support provided and sources of support (identified as networks by this author). Thus, two theoretical factor structures were proposed. One structure addresses the frequency of perceived social support from the four sources analysed: the partner, family, friends and the community. The other addresses satisfaction with perceived social support from the four sources. Based on the factorial structure of other validated instruments of social support, such as the MOS-SSS (Sherbourne \& Stewart, 1991; de la Revilla et al., 2005) or the DUKE-UNC Functional Social Support Questionnaire (Broadhead et al, 1988; CuellarFlores \& Dresch, 2012), the factorial structure took into account the types or functions of social support as the starting point to perform confirmatory factorial analysis. The adjustment statistics provided by the LISREL 8.30 software package and the recommendations provided by the Annals of Psychology (2013) were used to determine the following adjustment criteria: significant $\chi^{2} / \mathrm{gl}$, SRMR $<.8$, GFI $>.95$, $\mathrm{AGFI}>.95, \mathrm{NFI}>.95, \mathrm{CFI}>.95$, and RMSEA $<.05$.

Reliability analyses were conducted for the following three groups of items: a) the frequency of and satisfaction with perceived social support; b) the types of perceived social support (emotional, instrumental, and informational support); and c) the sources of perceived social support (partners, family, friends and the community). Hereafter, the term social support should be understood to mean perceived social support. Prior to the reliability analysis, the data were analysed for the absence of floor and ceiling effects. According to the recommendations provided by McHomey and Tarlov (1995), the percentage of participants who have extreme scores (i.e., minimum and maximum scores) must be less than 15\%. The minimum and maximum scores on the QFSSS of the frequency of and satisfaction with perceived social support were 12 and 60. The frequency analysis showed that the percentage of participants with these scores was less than $3.5 \%$.

Cronbach's alpha coefficient and corrected item-total correlation were used to evaluate the reliability of the QFSSS scores, where reliability is understood as the internal consistency of the items and internal consistency refers to the degree of similarity (homogeneity) between the elements or items comprising a scale (Pardo and Ruiz, 2002). Within Classical Test Theory, corrected item-test correlation is known as the homogeneity index and refers to the correlation between each item and the sum of the remaining items in the scale analysed (Warner, 2008). The corrected itemtotal correlation indicates the way each item in the scale contributes to measuring a common core construct of the scale (Guttman, 1954). According to Nurosis (1993), the corrected correlation of each item with the total must be more than 0.30 to accept that the items are uniformly associated with the scale to which they belong. 
In order to provide a more detailed measurement of the internal consistency of the scores using the QFSSS and the scores of each of its items, Guttman-Cronbach's alpha coefficient and the corrected item-total correlation were determined for the total sample of participants and for two subsamples of equal size formed by randomly dividing the total sample. Thus, the internal consistency of the instrument was tested by applying it to two different subsamples obtained from the original sample.

A correlational analysis was conducted using the Pearson $r$ statistic to assess the convergent validity of the QFSSS in relation to the MOS-SSS and the Eudemon Scale of Personal Well-being. In theory, there should be a positive correlation between the QFSSS and the latter two scales. The discriminant validity of the QFSSS scores was assessed through their correlation with the scores obtained on the Social and Emotional Loneliness Scale for Adults.

\section{Results}

\section{Structural Validity}

The QFSSS was designed to assess the frequency of and satisfaction with three types of social support (emotional, in- strumental, and informational) and all the potential sources of social support (partners, family, friends, and the community). Although this instrument is very versatile for practical applications, its versatility can hinder the analysis of its underlying factor structure. The items that comprise the instrument could be grouped into a 2-factor structure (frequency of social support/satisfaction with social support), a 3-factor structure (emotional, instrumental, and informational social support), or a 4-factor structure (social support from partners, family, friends, and the community). The literature on social support suggests that the frequency of social support does not necessarily follow the same pattern as satisfaction with social support (Fiorillo \& Sabatini, 2011; Phillips, Siu, Yeh, \& Cheng, 2008). Similarly, the perception of a high frequency of or satisfaction with one modality (e.g. instrumental social support) need not imply the perception of a high frequency of or satisfaction with another modality (e.g. emotional social support) (Burkey, Kim \& Breakey, 2011). However, consistent with the structure of the elements involved in social support (Tardy, 1985), it would be more useful to differentiate the dimensions of frequency of and satisfaction with social support and establish the various sources of support as elements by which to organize the different types of social support.

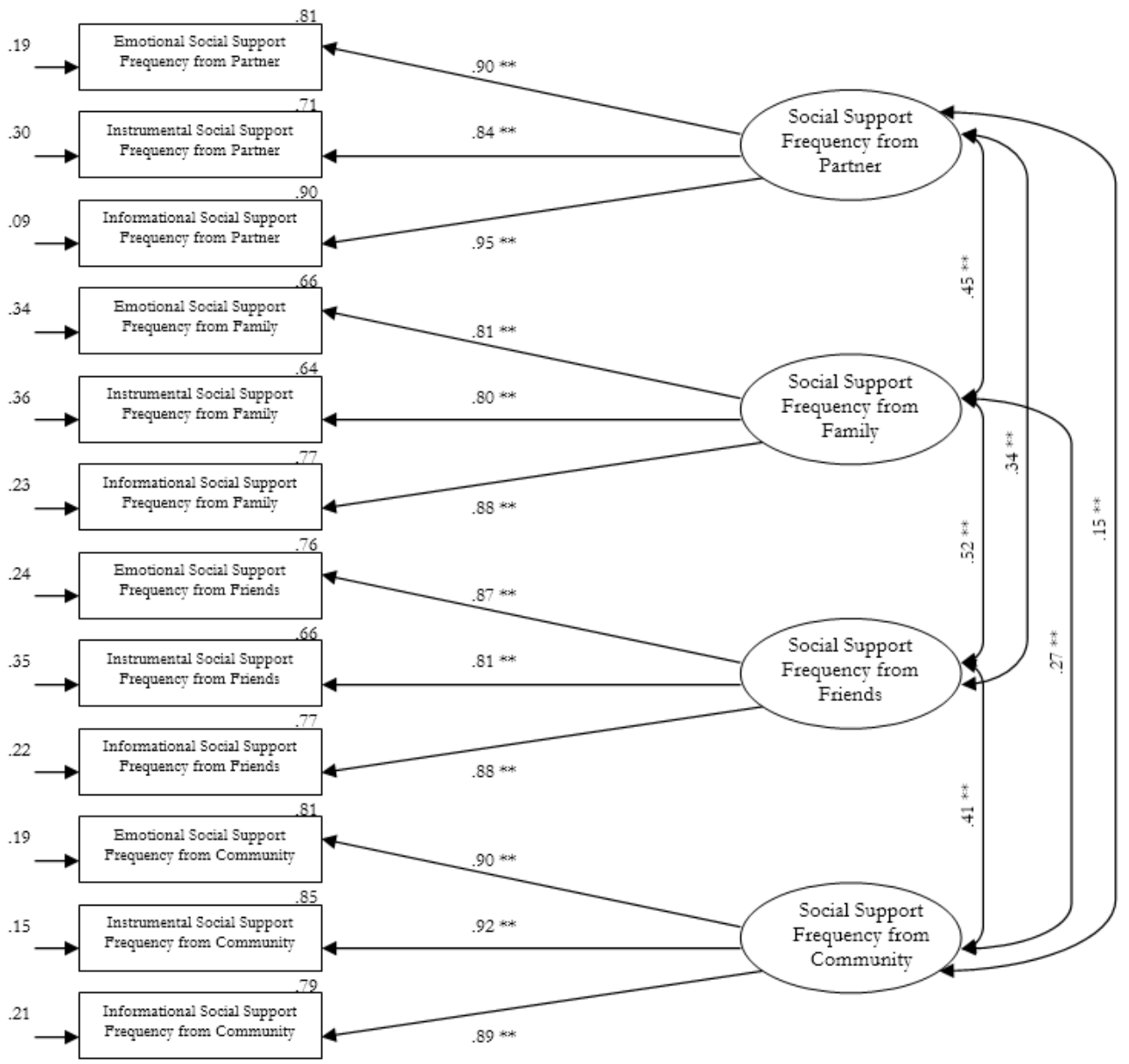

Figure 1. Proposed model number 1 applied on QFSSS items related to social support frequency. 


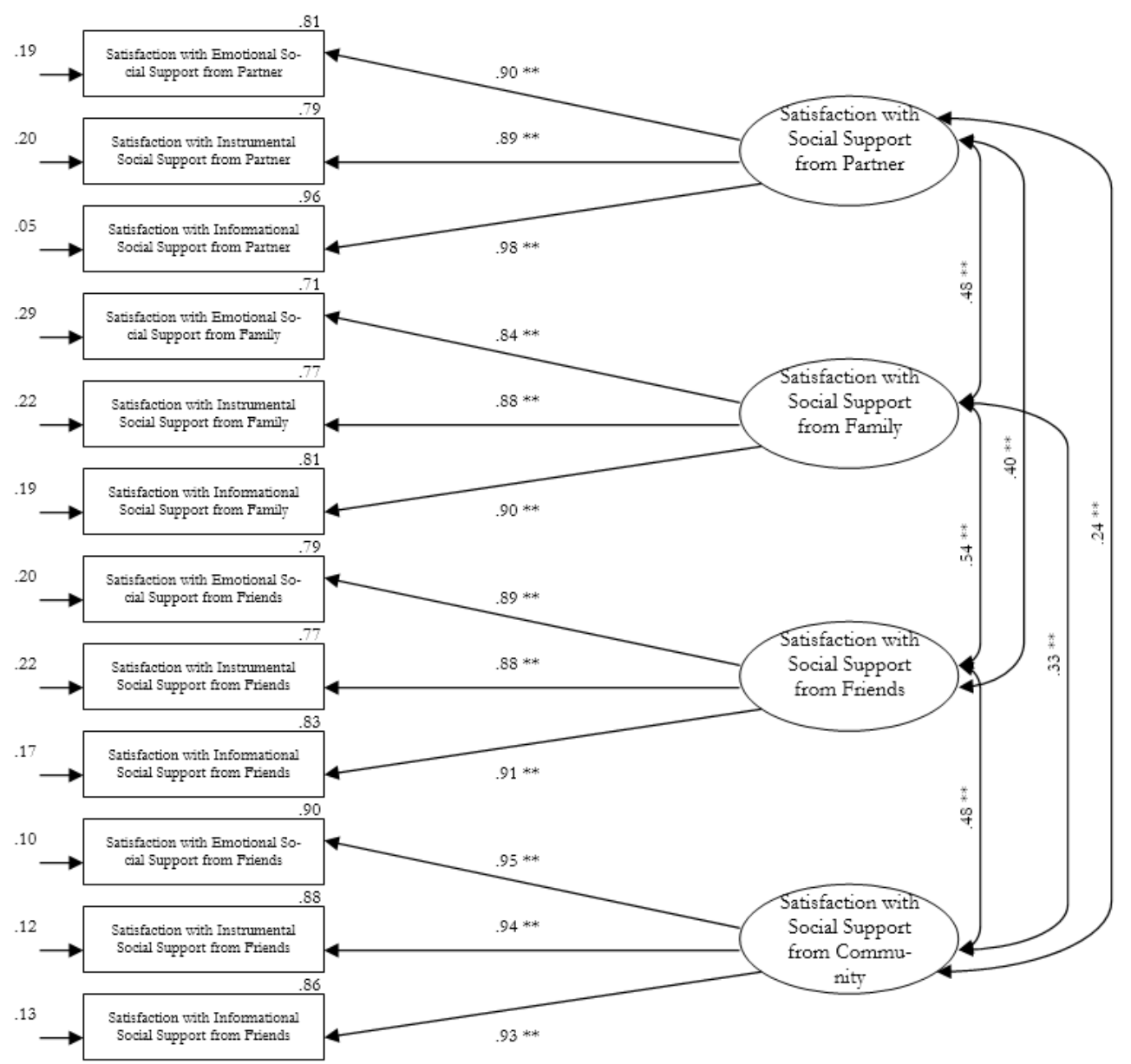

Figure 2. Proposed model number 2 applied on QFSSS items related to social support satisfaction.

Based on this approach, two structural equation models were created. The first model includes the 12 items on the frequency of social support that, according to the source of support to which they refer, would act as indicators of four latent variables or factors: frequency of social support from partners, family, friends, and the community (see Figure 1).
Similarly, the second model includes the 12 items on satisfaction with social support that would act as indicators of four latent variables or factors: satisfaction with social support from partners, family, friends, and the community (see Figure 2). No second-order factors were found in either model.

Table 2. Goodness of Fit Statistics for the Two Models

\begin{tabular}{|c|c|c|c|c|c|c|c|c|}
\hline Goodness of fit statistics & & $x^{2}$ & SRMR & GFI & AGFI & NFI & CFI & RMSEA \\
\hline \multirow[t]{2}{*}{ Obtained value } & $\begin{array}{l}\text { Model } 1 \\
n=1677\end{array}$ & $\begin{array}{c}928.99 \\
\mathrm{df}=48 \\
p=.001\end{array}$ & .03 & 1.00 & .99 & 1.00 & 1.00 & .10 \\
\hline & $\begin{array}{l}\text { Model } 2 \\
n=1677\end{array}$ & $\begin{array}{c}529.91 \\
\mathrm{df}=48 \\
p=.001\end{array}$ & .02 & 1.00 & 1.00 & 1.00 & 1.00 & .08 \\
\hline Recommended value & & $p>.05$ & $<.08$ & $>.95$ & $>.95$ & $>.95$ & $>.95$ & $<.05$ \\
\hline
\end{tabular}

Note: $\chi^{2}$ : Chi-Square; SRMR: Standardized Root Mean Square Residual; GFI: Goodness of Fit Index; AGFI: Adjusted Goodness of Fit Index; NFI: Normed Fit Index; CFI: Comparative Fit Index; RMSEA: Root Mean Square Error of Approximation.

The results show that the proposed models had acceptable global adjustment indicators (see Table 2) (Hu \& Bentler, 1999). Although the values obtained for $\chi^{2}$ would reject both models $(p>.05)$, the majority of the values of the other adjustment indicators were more than acceptable. These indica- tors included the Goodness of Fit Index (GFI), Standardized Root Mean Square Residual (SRMR), the Adjusted Goodness of Fit Index (AGFI), the Normed Fit Index (NFI), and the Comparative Fit Index (CFI). However, the Root Mean Square Error of Approximation (RMSEA) was the only indi- 
cator with lower values for the two models (.08, Model 2 and .10 , Model 1). Values less than .05 indicate a good fit, whereas values between .08 and 0.10 indicate an acceptable fit (MacCallum, Browne, \& Sugawara, 1996).

Model 2 showed some of the best indicators of adjustment of the measurement model to the observed data. The percentage of variance explained by the respective latent variables for each of the items included in the model was taken as the reference value. These percentages were always greater than $70 \%$ for model 2 (see Figure 1) and greater than $60 \%$ for model 1 (see Figure 2). Values greater than $50 \%$ of the variance explained by the latent variable showed that the indicator or item was a good measure of the underlying variable, thus indicating that the measurement model had a good fit.

Finally, adjustment to the proposed structural models was positive for both models (see Figures 1 and 2), as all the estimated parameters were nonzero and statistically significant $(p<.01)$.

\section{Score Reliability}

Results are shown for the three groups of items: the frequency of and satisfaction with social support, the type of support, and the potential sources of support.

\section{a) Reliability analyses of frequency of and satisfaction with social support}

Table 3 shows that the values of Guttman-Cronbach's alpha indicated good internal consistency (i.e., greater than .80) (George \& Mallery, 2003) for the items on the frequency of social support (total sample, $\alpha=.840$ ) and satisfaction with social support (total sample, $\alpha=0.867$ ). In addition, analysis of the total sample indicated that the items were internally consistent (i.e., within the range $0.3-0.7$ ), as the corrected item-total correlations ranged from .435 to .575 for frequency of social support and from .499 to .607 for satisfaction with social support. The values obtained for each subsample were also within the range indicated (see Table 3).

Table 3. Frequency of and Satisfaction With Social Support: Guttman-Cronbach's Alpha Reliability Analysis.

\begin{tabular}{|c|c|c|c|c|c|c|}
\hline & \multicolumn{3}{|c|}{$\begin{array}{c}\text { Corrected correlation } \\
\text { Item-Total } \\
\end{array}$} & \multicolumn{3}{|c|}{ Guttman-Cronbach's Alpha } \\
\hline & Total Sample & $\begin{array}{c}\text { Sub-group } \\
\text { One } \\
n=1024\end{array}$ & $\begin{array}{c}\text { Sub-group } \\
\text { Two } \\
n=1024\end{array}$ & Total Sample & $\begin{array}{c}\text { Sub-group } \\
\text { One } \\
n=1024 \\
\end{array}$ & $\begin{array}{c}\text { Sub-group } \\
\text { Two } \\
n=1024\end{array}$ \\
\hline Frequency of social support received items & & & & .840 & .845 & .836 \\
\hline Emotional social support from partner & .492 & .503 & .482 & & & \\
\hline Instrumental social support from partner & .466 & .469 & .464 & & & \\
\hline Informational social support from partner & .545 & .544 & .547 & & & \\
\hline Emotional social support from family & .502 & .496 & .507 & & & \\
\hline Instrumental social support from family & .491 & .521 & .462 & & & \\
\hline Informational social support from family & .539 & .558 & .520 & & & \\
\hline Emotional social support from friends & .569 & .584 & .557 & & & \\
\hline Instrumental social support from friends & .533 & .531 & .535 & & & \\
\hline Informational social support from friends & .575 & .608 & .543 & & & \\
\hline Emotional social support from community & .457 & .458 & .455 & & & \\
\hline Instrumental social support from community & .450 & .441 & .460 & & & \\
\hline Informational social support from community & .435 & .434 & .437 & & & \\
\hline Satisfaction with social support received items & & & & .867 & .880 & .855 \\
\hline Emotional social support from partner & .508 & .521 & .498 & & & \\
\hline Instrumental social support from partner & .499 & .517 & .484 & & & \\
\hline Informational social support from partner & .566 & .591 & .544 & & & \\
\hline Emotional social support from family & .510 & .537 & .483 & & & \\
\hline Instrumental social support from family & .533 & .562 & .505 & & & \\
\hline Informational social support from family & .549 & .583 & .514 & & & \\
\hline Emotional social support from friends & .598 & .618 & .579 & & & \\
\hline Instrumental social support from friends & .598 & .612 & .585 & & & \\
\hline Informational social support from friends & .607 & .643 & .571 & & & \\
\hline Emotional social support from community & .570 & .594 & .547 & & & \\
\hline Instrumental social support from community & .559 & .581 & .537 & & & \\
\hline Informational social support from community & .556 & .581 & .531 & & & \\
\hline
\end{tabular}

\section{b) Reliability analyses of the type of social support}

The values of Cronbach's alpha (see Table 4) were slightly lower than in the previous case, but close to .80 (instrumental social support $\alpha=.763$; emotional social support $\alpha=.780$; and informational social support $\alpha=$ .795). The corrected item-total correlations for the total sample ranged from .390 to .562 for emotional support, from .353 to .560 for instrumental support, and from .392 to .580 for informational support. The values ob- 
tained are acceptable for the total sample and for both subsamples (see Table 4). These results show that the
QFSSS items on perceived social support had adequate internal consistency.

Table 4. Types of Social Support: Guttman-Cronbach's Alpha Reliability Analysis.

\begin{tabular}{|c|c|c|c|c|c|c|}
\hline & \multicolumn{3}{|c|}{$\begin{array}{l}\text { Corrected correlation } \\
\text { Item-Total }\end{array}$} & \multicolumn{3}{|c|}{ Guttman-Cronbach's Alpha } \\
\hline & \multicolumn{3}{|c|}{ Sub-group Sub-group } & \multirow{2}{*}{ Total Sample } & \multicolumn{2}{|c|}{ Sub-group Sub-group } \\
\hline & Total Sample & $\begin{array}{c}\text { One } \\
n=1024\end{array}$ & $\begin{array}{c}\text { Two } \\
n=1024\end{array}$ & & $\begin{array}{c}\text { One } \\
n=1024\end{array}$ & $\begin{array}{c}\text { Two } \\
n=1024\end{array}$ \\
\hline Emotional social support received items & & & & .780 & .786 & .774 \\
\hline Frequency of social support received from partner & .488 & .508 & .470 & & & \\
\hline Satisfaction with social support received from partner & .496 & .515 & .480 & & & \\
\hline Frequency of social support received from family & .510 & .508 & .511 & & & \\
\hline Satisfaction with social support received from family & .520 & .528 & .511 & & & \\
\hline Frequency of social support received from friends & .513 & .508 & .519 & & & \\
\hline Satisfaction with social support received from friends & .562 & .567 & .557 & & & \\
\hline Frequency of social support received from community & .390 & .382 & .397 & & & \\
\hline Satisfaction with social support received from community & .426 & .450 & .403 & & & \\
\hline Instrumental social support received items & & & & .763 & .771 & .756 \\
\hline Frequency of social support received from partner & .435 & .431 & .438 & & & \\
\hline Satisfaction with social support received from partner & .460 & .461 & .459 & & & \\
\hline Frequency of social support received from family & .480 & .510 & .451 & & & \\
\hline Satisfaction with social support received from family & .533 & .567 & .501 & & & \\
\hline Frequency of social support received from friends & .508 & .515 & .502 & & & \\
\hline Satisfaction with social support received from friends & .560 & .577 & .543 & & & \\
\hline Frequency of social support received from community & .353 & .339 & .367 & & & \\
\hline Satisfaction with social support received from community & .397 & .405 & .390 & & & \\
\hline Informational social support received items & & & & .795 & .809 & .771 \\
\hline Frequency of social support received from partner & .513 & .520 & .513 & & & \\
\hline Satisfaction with social support received from partner & .518 & .546 & .518 & & & \\
\hline Frequency of social support received from family & .513 & .535 & .513 & & & \\
\hline Satisfaction with social support received from family & .555 & .578 & .555 & & & \\
\hline Frequency of social support received from friends & .557 & .583 & .557 & & & \\
\hline Satisfaction with social support received from friends & .580 & .612 & .580 & & & \\
\hline Frequency of social support received from community & .392 & .390 & .392 & & & \\
\hline Satisfaction with social support received from community & .430 & .452 & .430 & & & \\
\hline
\end{tabular}

\section{c) Reliability analyses of the source of support}

Table 5 shows that the highest values of Cronbach's alpha were obtained for groups of items that differentiated between social support from partners (total sample, $\alpha=.952$ ), followed by friends (total sample, $\alpha=.923$ ), the community (total sample, $\alpha=0.917$ ), and friends (total sample, $\alpha=$ .914). In contrast to the two previous cases (see Table 5), the corrected item-total correlations were more than 0.7 for the total sample and the two subsamples, which indicates that that the different items are used to measure the same attribute. This finding suggests that when the participants evaluated the frequency of and satisfaction with social support from each source they tended not to differentiate between the types of support (emotional, instrumental, and informational) from each source.

The following ranges were obtained for the corrected item-total correlations: social support received from partners (from .798 to .880), social support from friends (from .704 to .812), social support from the community (from .697 to .819 ), and social support from family (from .719 to .813).

\section{Convergent and discriminant validity}

Table 6 shows the mean and standard deviation of each of the variables analysed. All the correlations were significant $(p<.01)$. The results show that the positive or negative sign of the $r$ values obtained were consistent with the predicted association between each pair of variables analysed. Thus, the nine measures of social support obtained using the QFSSS (SSFrequency, SS-Satisfaction, SS-Emotional, SS-Instrumental, SS-Informational, SS-Partner, SS-Family, SS-Friends, SSCommunity) had high positive correlation coefficients with the five social support variables obtained using the MOS-SSS scale (total support, emotional support, instrumental support, affectionate support, and social associations). Similarly, the nine measures had positive correlations with the two positive measures of well-being on the EUDEMON scale (total wellbeing and positive well-being) and negative correlations with the measure of the absence of well-being. As predicted, all the correlation coefficients between the nine measures of social support and the four variables of loneliness (total loneliness, family 
loneliness, romantic loneliness, and social loneliness) were nega-

tive and significant.

Table 5. Sources of Social Support: Guttman-Cronbach's Alpha Reliability Analysis.

\begin{tabular}{|c|c|c|c|c|c|c|}
\hline & \multicolumn{3}{|c|}{$\begin{array}{c}\text { Corrected correlation } \\
\text { Item-Total } \\
\end{array}$} & \multicolumn{3}{|c|}{ Guttman-Cronbach’s Alpha } \\
\hline & Total Sample & $\begin{array}{c}\text { Sub-group } \\
\text { One } \\
n=1024\end{array}$ & $\begin{array}{c}\text { Sub-group } \\
\text { Two } \\
\mathrm{n}=1024\end{array}$ & Total Sample & $\begin{array}{c}\text { Sub-group } \\
\text { One } \\
n=1024\end{array}$ & $\begin{array}{c}\text { Sub-group } \\
\text { Two } \\
\mathrm{n}=1024\end{array}$ \\
\hline Social support received from partner items & & & & .952 & .945 & .957 \\
\hline Frequency of emotional social support & .867 & .856 & .876 & & & \\
\hline Satisfaction with emotional social support & .865 & .849 & .879 & & & \\
\hline Frequency of instrumental social support & .798 & .762 & .830 & & & \\
\hline Satisfaction with instrumental social support & .859 & .847 & .869 & & & \\
\hline Frequency of informational social support & .840 & .830 & .850 & & & \\
\hline Satisfaction with informational social support & .880 & .863 & .894 & & & \\
\hline Social support received from family items & & & & .914 & .913 & .914 \\
\hline Frequency of emotional social support & .742 & .744 & .741 & & & \\
\hline Satisfaction with emotional social support & .749 & .746 & .753 & & & \\
\hline Frequency of instrumental social support & .719 & .702 & .735 & & & \\
\hline Satisfaction with instrumental social support & .776 & .771 & .780 & & & \\
\hline Frequency of informational social support & .762 & .774 & .751 & & & \\
\hline Satisfaction with informational social support & .813 & .815 & .811 & & & \\
\hline Social support received from friends items & & & & .923 & .928 & .918 \\
\hline Frequency of emotional social support & .807 & .811 & .803 & & & \\
\hline Satisfaction with emotional social support & .812 & .813 & .811 & & & \\
\hline Frequency of instrumental social support & .704 & .712 & .697 & & & \\
\hline Satisfaction with instrumental social support & .784 & .808 & .761 & & & \\
\hline Frequency of informational social support & .786 & .802 & .770 & & & \\
\hline Satisfaction with informational social support & .802 & .816 & .788 & & & \\
\hline Social support received from community items & & & & .917 & .915 & .919 \\
\hline Frequency of emotional social support & .737 & .722 & .751 & & & \\
\hline Satisfaction with emotional social support & .806 & .806 & .807 & & & \\
\hline Frequency of instrumental social support & .697 & .689 & .704 & & & \\
\hline Satisfaction with instrumental social support & .789 & .791 & .786 & & & \\
\hline Frequency of informational social support & .743 & .740 & .747 & & & \\
\hline Satisfaction with informational social support & .819 & .817 & .821 & & & \\
\hline
\end{tabular}

Table 6. Means, Standard Deviations, and Measures Correlations for the Total Sample.

\begin{tabular}{|c|c|c|c|c|c|c|c|c|c|c|c|c|c|c|c|c|c|c|c|c|c|c|}
\hline \multicolumn{23}{|l|}{ Total sample $(n=2042)$} \\
\hline & M & $S D$ & 1 & 2 & 3 & 4 & 5 & 6 & 7 & 8 & 9 & 10 & 11 & 12 & 13 & 14 & 15 & 16 & 17 & 18 & 19 & 20 \\
\hline 1. Social Support - Frequency & 37.29 & 9.73 & & & & & & & & & & & & & & & & & & & & \\
\hline 2. Social Support - Satisfaction & 41.00 & 10.10 & $.84^{* *}$ & & & & & & & & & & & & & & & & & & & \\
\hline 3. Social Support - Emotional & 28.09 & 6.03 & $.88^{* *}$ & $.89 * *$ & & & & & & & & & & & & & & & & & & \\
\hline 4. Social Support - Instrumental & 26.77 & 6.04 & $.89 * *$ & $.89 * *$ & * $.81^{* *}$ & & & & & & & & & & & & & & & & & \\
\hline 5. Social Support - Informational & 27.12 & 6.34 & $.97^{* *}$ & $.90 * *$ & $* .85^{* *}$ & $.83^{* *}$ & & & & & & & & & & & & & & & & \\
\hline 6. Social Support - Partner & 23.25 & 7.11 & $.64 * *$ & $.63^{* *}$ & * $.66^{* *}$ & $.64 * *$ & $.63^{* *}$ & & & & & & & & & & & & & & & \\
\hline 7. Social Support - Family & 24.29 & 5.45 & $.62^{* *}$ & $.58^{* *}$ & * $.65^{* *}$ & $.66^{* *}$ & $.67^{* *}$ & $.34 * *$ & & & & & & & & & & & & & & \\
\hline 8. Social Support - Friends & 20.94 & 6.01 & $.64^{* *}$ & * $.61 * *$ & * $.68^{* *}$ & $.70^{* *}$ & $.71 * *$ & $.29 * *$ & $.42 * *$ & & & & & & & & & & & & & \\
\hline 9. Social Support - Community & 13.98 & 6.51 & $.52 * *$ & $.57 * *$ & *. $.61 * *$ & $.59 * *$ & $.63^{* *}$ & $.16^{* *}$ & $.24 * *$ & $.37 * *$ & & & & & & & & & & & & \\
\hline 10. MOS-Total Support & 78.25 & 13.84 & $.54^{* *}$ & $.50^{* *}$ & $* .59 * *$ & $.54 * *$ & $.55^{* *}$ & $.54 * *$ & $.48^{* *}$ & $.41^{* *}$ & $.19^{* *}$ & & & & & & & & & & & \\
\hline 11. MOS- Emotional Support & 32.13 & 6.69 & $.49 * *$ & $.46^{* *}$ & $* .55^{* *}$ & $.50^{* *}$ & $.54^{* *}$ & $.47^{* *}$ & $.45^{* *}$ & $.41^{* *}$ & $.20^{* *}$ & $.94 * *$ & & & & & & & & & & \\
\hline 12. MOS- Instrumental Support & 16.97 & 3.49 & $.35^{* *}$ & $.33^{* *}$ & * $.38 * *$ & $.39 * *$ & $.37^{* *}$ & $.39 * *$ & $.38^{* *}$ & $.22 * *$ & $.13^{* *}$ & $.75^{* *}$ & $* .57 * *$ & & & & & & & & & \\
\hline 13. MOS- Affective Support & 12.84 & 2.56 & $.48^{* *}$ & $.44 * *$ & $* .54 * *$ & $.45^{* *}$ & $.44^{* *}$ & $.58^{* *}$ & $.35^{* *}$ & $.27 * *$ & $.13^{* *}$ & $.81 * *$ & $* .68^{* *}$ & $.53^{* *}$ & & & & & & & & \\
\hline 14. MOS - Social Relationships & 16.31 & 3.29 & $.50^{* *}$ & $.47 * *$ & * . $.54 * *$ & $.50^{* *}$ & $.52^{* *}$ & $.47^{* *}$ & $.41^{* *}$ & $.44 * *$ & $.18^{* *}$ & $.87 * *$ & * . $.78^{* *}$ & $.52^{* *}$ & $.68^{* *}$ & & & & & & & \\
\hline 15. SELSA - Total Loneliness & 37 & 15.76 & $-.59 * *$ & *-.60** & $*_{-}^{*} .66^{* *}$ & $-.58^{* *}$ & $-.59 * *$ & $*^{*}-64 * *$ & $-.46 * *$ & $-.43 * *$ & $-.17 * *$ & *-.56** & $*-.51 * *$ & $-.36 * *$ & $-.61 * *$ & *-.53** & & & & & & \\
\hline 16. SELSA - Family Loneliness & 9.53 & 5.53 & $-.39 * *$ & $*-.41 * *$ & $*-.49 * *$ & $-.40 * *$ & k-.43** & $*-.32 * *$ & $-.59 * *$ & $-.28 * *$ & $-.13 * *$ & *-.47** & $*-.42 * *$ & $-.37^{* *}$ & $-.44 * *$ & *-.38** & $* .72 * *$ & & & & & \\
\hline 17. SELSA-Romantic Loneliness & 14.51 & 9.11 & $-.49 * *$ & $*-.49 * *$ & $*-.52 * * \ldots$ & $-.44 * *$ & $-.45^{* *}$ & $*_{-}^{*} .76^{* *}$ & $-.20 * *$ & $-.11 * *$ & $-.07 * *$ & *-.43** & $*-.34 * *$ & $-.27 * *$ & $-.56 * *$ & * $-.37 * *$ & $* .80^{* *}$ & $.33^{* *}$ & & & & \\
\hline 18. SELSA - Social Loneliness & 13.02 & 6.46 & $-.42 * *$ & *-.43** & $*-.51 * *$ & $-.47 * *$ & $-.48^{* *}$ & $*-.27 * *$ & $-.33 * *$ & $-.65^{* *}$ & $-.19 * *$ & *-.41** & $*-.40 * *$ & $-.18^{* *}$ & $-.33^{* *}$ & *-.45** & $* .70^{* *}$ & $.43^{* *}$ & $.24^{* *}$ & & & \\
\hline 19. EUDEMON - Total Well-being & 77.42 & 10.96 & $.40^{* *}$ & $.44^{* *}$ & $.50 * *$ & $.43^{* *}$. & $.43^{* *}$ & $.43^{* *}$ & $.37^{* *}$. & $.38^{* *}$. & $.16^{* *}$ & $.46^{* *}$ & $.41 * *$ & $.29 * *$. & $.43^{* *}$ & $.46^{* *}$ & $-.61 * *$ & $-.49 * *$ & $-.41 * *$ & $-.49 * *$ & & \\
\hline $\begin{array}{l}\text { 20. EUDEMON - Negative } \\
\text { Dimension }\end{array}$ & 54.72 & 8.56 & $-.37 * *$ & * $-.40^{* *}$ & $*-.46 * *$ & $-.40^{* *}$ & $-39 * *$ & $-.41 * *$ & $-35^{* *}$ & $-34^{* *}$ & $-.13 * *$ & k-.42** & $*_{-} .38 * *$ & $-27^{* *}$ & $-.39 * *$ & *-.42** & $* .57^{* *}$ & $.46^{* *}$. & $.40^{* *}$. & $.45^{* *}$ & $-.97 * *$ & \\
\hline $\begin{array}{l}\text { 21. EUDEMON - Positive } \\
\text { Dimension }\end{array}$ & 22.69 & 3.42 & $.37^{* *}$ & $.39 * *$ & $.45^{* *}$ & $.38^{* *}$ & $.40^{* *}$ & $.34^{* *}$ & $.30^{* *}$. & $.37 * *$ & $.18^{* *}$ & $.41^{* *}$ & $.36^{* *}$ & $.25^{* *}$ & $.39^{* *}$ & $.42 * *$ & $-.50^{* *}$ & $-.43^{* *}$ & $-.31^{* *}$ & $-.42^{* *}$. & $.78^{* *}-$ & $-.60^{* *}$ \\
\hline
\end{tabular}




\section{Discussion}

This study examined the psychometric properties of the QFSSS by applying it to a representative sample of the population. The results show excellent internal consistency for the groups of items related to sources of support, good internal consistency for the groups of items related to the frequency of and satisfaction with social support, and acceptable consistency for the groups of items related to the three types of social support. The values of the corrected item-total correlations confirmed the high level of homogeneity between items within all these groups. However, the correlations higher than 0.7 related to the sources of social support suggest that the participants tended not to discriminate between the types of social support from each source.

The criterion validity of the QFSSS shows that the scores correlated positively and significantly with measures of social support and positive well-being (convergent validity), and negatively with measures of loneliness and negative wellbeing (discriminant validity).

Regarding the construct validity of the QFSSS, confirmatory factor analysis verified a factor structure that includes four factors. These factors correspond to the four sources of social support analysed. A factor structure was verified for items related to both the frequency of social support and those measuring satisfaction with social support. Nevertheless, the adjustment indicators showed that satisfaction with perceived social support had a better fit to the model than frequency of social support. The results indicate that this 4element factor structure had acceptable adjustment, as shown by the global indicators and the percentage of variance explained by the corresponding latent variables. The statistical significance and the percentages of explained variance of all the estimated coefficients indicated that the data obtained from the proposed measurement model had a good fit, which further confirmed the factor structure.

Given that the structure of the QFSSS items is based on the sources of social support, the instrument is highly versatile and can be used in a variety of settings and applied in many ways. For example, it could be used to analyse the frequency of and satisfaction with social support from family members, differentiating between social support from the nuclear family and social support from the extended family. Three sources of support could be analysed within organizational settings: superiors, colleagues or members on the same level within the organizational hierarchy, and subordinates.

\section{References}

Annals of Psychology (2013). Guia editorial para la presentación de trabajos de validación de tests en Ciencias Sociales y de la Salud. Retrieved from: http://www.um.es/analesps/informes/GuiaValidacionTestsAnalesps2 013.pdf

Ayala, A., Rodríguez, C., Frades, B., João, M., Martínez, P., Fernández, G., \& Rojo, F. (2012). Propiedades psicométricas del Cuestionario de Apoyo Social Funcional y de la Escala de Soledad en adultos mayores no institucionalizados en España. Gaceta Sanitaria, 26(4), 317-324.
Nevertheless, the statistical behaviour of the QFSSS would require further analysis when applied in such settings. Its versatility and efficiency in different contexts has been verified by applying the QFSSS in studies on different populations (Hombrados-Mendieta et al., 2012, HombradosMendieta, García-Martín, \& Gómez-Jacinto, 2013).

Although the sample to which the QFSSS was applied was representative of the Spanish population, further research on its use in cross-cultural samples would support the generalizability of the results. The establishment of mean reference values for different cultural contexts would allow comparisons between populations. The study could also be improved by administering the QFSSS to different groups in different social situations within the same culture. It would also be useful to conduct longitudinal studies to obtain measures of temporal stability of the scores obtained with this scale.

\section{Conclusions}

The QFSSS is a promising psychometric tool for the comprehensive assessment of perceived social support in different settings and diverse populations. It provides a valid and reliable measure of three functional types of social support and perceived social support from the social network. The QFSSS is congruent with the work of Tardy (1985) on the different aspects of the social support construct. Although the measure does not take into account all the aspects addressed by Tardy (1985), it takes into account the three dimensions of analysis that are highly relevant to the assessment of social support. These features raise the incremental validity of the questionnaire in relation to other partial measures of perceived social support. Thus, the QFSSS is a useful tool for researchers and professionals working in the setting of applied psychology. The authors are currently adapting the questionnaire to the measurement of social support offered. Although this variant of social support is receiving increased attention in the field of psychology, tools for its assessment remain scarce.

Acknowledgements.- This study is part of a Project I+D (Ref.: PSI2013-40508-P). The authors express their gratitude to the psychology students who participated as interviewers in the present study, and to all the participants who kindly collaborated in data collection.

Barrera, M. (1980). A method for the assessment of social support networks in community survey research. Connections, 3, 8-13.

Barrera, M. (1981). Social support in the adjustment of pregnant adolescents: Assessments issues. In B. H. Gottlieb (Ed.), Social networkes and social support (pp. 69-96). Beverly Hills, CA: Sage.

Blair, K. L., \& Holmberg, D. (2008). Perceived social network support and well-being in same-sex versus mixed-sex romantic relationships. Journal 
of Social and Personal Relationships, 25(5), 769-791. doi: $10.1177 / 0265407508096695$

Bordes, V., Sand, J. K., Arredondo, P., Robinson, S. E., \& Dixon, A. (2006). Validation of four measures of social support with latina/o and non-hispanic white undergraduates. Hispanic Journal of Behavioral Sciences, 28(1), 65-83. doi: 10.1177/0739986305283299

Broadhead, W. E., Gehlbach, S. H., Degruy, F. V., \& Kaplan, B. H. (1988). The DUKE-UNC functional social support questionnaire: measurement of social support in family medicine patients. Medical Care, 26, $709-723$.

Brown, T. A. (2006). Confirmatory factor analysis for applied research. New York: The Guilford Press.

Brown, L. D., Tang, X., \& Hollman, R. L. (2014). The Structure of Social Exchange in Self-help Support Groups: Development of a Measure. American Journal of Community Psychology, 53(1-2), 83-95. doi: 10.1007/s10464-013-9621-3

Burkey, M. D., Kim, Y. A., \& Breakey, W. R. (2011). The role of social ties in recovery in a population of homeless substance abusers. Addictive Disorders and their Treatment, 10(1), 14-20. doi: 10.1097/ADT.0b013e3181ea7511

Chatzisarantis, N. L., Hagger, M. S., \& Smith, B. (2007). Influences of perceived autonomy support on physical activity within the theory of planned behaviour. European Journal of Social Psychology, 37(5), 934-954. doi: $10.1002 /$ ejsp. 407

Cohen, S., \& Hoberman, H. (1983). Positive events and social supports as buffers of life change stress. Journal of Applied Social Psychology, 13, 99125. doi: 10.1111/j.1559-1816.1983.tb02325.x

Cohen, S. \& Wills, T. A. (1985). Stress, Social Support and de Buffering Hypothesis. Psychological Bulletin, 98(2), 310-357. doi: 10.1037//00332909.98.2.310

Cohen, S., Underwood, L. G., \& Gottlieb, B. H. (2001). Social Support Measurement and Intervention: A Guide for Health and Social Scientist. New York: Oxford University Press.

Cuellar-Flores, I., \& Dresch, V. (2012). Validation of the Duke-UNK-11 functional social support questionnaire in caregivers. RIDEP, 34(1), 89101. Retrieved from: http://www.aidep.org/03_ridep/R34/ART\%204.pdf

de la Revilla, L., Luna, J., Bailón, E., \& Medina, I. (2005). Validación del cuestionario MOS de apoyo social en Atención Primaria [Validation of a Questionnaire to Measure Social Support in Primary Care]. Medicina de Familia (And), 6(1), 10-18. Retrieved from: http://www.samfyc.es/Revista/PDF/v6n1/03.pdf

DiTomasso, E., \& Spinner, B. (1993). The development and initial validation of the Social and Emotional Loneliness Scale for Adults (SELSA). Personality and Individual Differences, 14, 127-134. doi: 10.1016/01918869(93) 90182-3

DiTomasso, E., Brannen, C., \& Best, L. A. (2004). Measurement and validity characteristics of the short version of the social and emotional loneliness scale for adults. Educational and Psychological Measurement, 64, 99119. doi: $10.1177 / 0013164403258450$

Ekbäck, M., Benzein, E., Linderg, M., \& Årestedt, K. (2013). The Swedish version of the multidimensional scale of perceived social support (MSPSS) - a psychometric evaluation study in women with hirsutism and nursing students. Health and Quality of Life Outcomes, 11(1), 168. doi: $10.1186 / 1477-7525-11-168$

Fierro, A., \& Rando, B. (2007). Escala Eudemon de bienestar personal: características psicométricas [Eudemon personal well-being Scale: psychometric properties]. Anuario de Psicologia, 38(3), 401-412. Retrieved from: http://www.ub.edu/psicologia/castellano/anuario-de-psicologia

Fiorillo, D., \& Sabatini, F. (2011). Quality and quantity: The role of social interactions in self-reported individual health. Social Science and Medicine, 73(11), 1644-1652. doi: 10.1016/j.socscimed.2011.09.007

George, D., \& Mallery, P. (2003). SPSS for Windows step by step: A simple guide and reference. 11.0 update (4th ed.). Boston: Allyn \& Bacon.

Gilbert, P. A., \& Rhodes, S. D. (2012). Psychometric Performance of a Novel Measure of Social Support Among Spanish-Speaking Immigrant Latino Gay Men. Hispanic Journal of Behavioral Sciences, 34(3), 491-504. doi: $10.1177 / 0739986312446290$
Gottlieb, B. H. (1983). Social support as a focus for integrative research in psychology. American Psychologist, 38(3), 278-287. doi: 10.1037/0003066X.38.3.278

Gottlieb, B. H., \& Bergen, A. E. (2010). Social support concepts and measures. Journal of Psychosomatic Research, 69(5), 511-520. doi: 10.1016/j.jpsychores.2009.10.001

Guttman, L. B. (1954). A new approach to factor analysis: The radex. In P. F. Lazarsfeld (Ed.), Mathematical thinking in the social sciences (pp. 258349). New York: Columbia University Press.

Hlebec, V., \& Kogovšek, T. (2013). Different approaches to measure egocentered social support networks: a meta-analysis. Quality \& Quantity, 47(6), 3435-3455. doi: 10.1007/s11135-012-9731-2

Holden, L., Lee, C., Jockey, R., Ware, R. S., \& Dobson, A. J. (2014). Validation of the MOS Social Support Survey 6-item (MOS-SSS-6) measure with two large population-based samples of Australian women. Quality of Life Research, 23, 2849-2853. doi: 10.1007/s11136-014-0741-5

Hombrados-Mendieta, I., Gómez-Jacinto, L., Domínguez-Fuentes, J. M., García-Leiva, P., \& Castro-Travé, M. (2012). Types of social support provided by parents, teachers and classmates during adolescence. Jour nal of Community Psychology, 40(6), 645-664. doi: 10.1002/jcop.20523

Hombrados-Mendieta, I., García-Martín, M. A., \& Gómez-Jacinto, L. (2013). The Relationship Between Social Support, Loneliness, and Subjective Well-Being in a Spanish Sample from a Multidimensional Perspective. Social Indicators Research, 114, 1013-1034. doi: 10.1007/s11205012-0187-5

House, J. S. (1981). Work Stress and Social Support. Reading: Addison-Wesley.

House, J. S., \& Kahn, R. L. (1985). Measures and concepts of social support. En S. Cohen \& L.S. Syme (Eds.), Social Support and Health (pp. 83108). London: Academic Press.

House, J. S., Landis, K. R., \& Umberson, D. (1988). Social Relationships and Health. Science, 241, 540-545. doi: 10.1126/science.3399889

Hu, L., \& Bentler, P. M. (1999). Cutoff criteria for fit indexes in covariance structure analysis: Conventional criteria versus new alternatives. Structural Equation Modeling, 6(1), 1-55. doi: 10.1080/10705519909540118

I.N.E. (2009). Padrón: Población por Municipios (Census: Population by Municipalities7. Instituto Nacional de Estadística: Madrid. Retrieved from: www.ine.es

Jöreskog, K. G., \& Sörbom, D. (1993). LISREL 8: Structural equation modeling with the SIMPLIS command language. Hillsdale, N. J.: Lawrence Erlbaum Associates.

Lin, N. (1986). Conceptualizing social support. En N. Lin, A. Dean \& W. Ensel (Eds.). Social support, life events and depression (pp. 17-30). New York: Academic Press.

Lin, N., Simeone, R. S., Ensel, W. M., \& Kuo, W. (1979). Social support, stressful life events and illness: A model and empirical test. Journal of Health and Social Behavior, 20(2), 108-119.

López, I., Menéndez, S., Lorente, B., Jiménez, L., Hidalgo, M.V., \& Sánchez, J. (2007). Evaluation of social support by means of the Scale ASSIS: description and results in a sample of mothers in situation of psychosocial risk. Intervención Psicosocial, 16(3), 323-337.

Lubben, J. (1988). Assessing social networks among elderly populations. Family and community bealth, 11(3), 42-52.

Lyons, J. S., Perrota, P., \& Hancher-Kvam, S. (2010). Perceived Social Support from Family and Friends: Measurements Disparate Samples. Jour nal of Personality Assessment, 52(1), 42-47. doi: 10.1207/s15327752jpa5201_3

Martos, M. J., \& Pozo, C. (2011). Apoyo funcional vs. Disfuncional en una muestra de pacientes crónicos. Su incidencia sobre la salud y el cumplimiento terapéutico [Functional versus non-functional social support in a simple of chronic patients. Repercusión on health and treatment compliance]. Anales de Psicología, 27(1), 47-57. Retrieved from: http://revistas.um.es/analesps/article/view/113461/107451

MacCallum, R. C., Browne, M. W., and Sugawara, H., M. (1996). Power Analysis and Determination of Sample Size for Covariance Structure Modeling. Psychological Methods, 1(2), 130-149. doi: 10.1037/1082989X.1.2.130

McHorney, C. A. y Tarlov, A. R. (1995). Individual-patient monitoring in clinical practice: Are available health status surveys adequate? Quality of Life Research, 4, 293-307. 
Mas, L., Amador, J. A., Gómez, J., \& Lalucat, L. (2013). Validation of the modified DUKE-UNC Functional Social Support Questionnaire in patients with schizophrenia. Social Psychiatry and Psychiatric Epidemiology, 48, 1675-1685. doi: 10.1007/s00127-012-0633-3

Melling, B., \& Houguet-Pincham, T. (2011). Online peer support for individuals with depression: A summary of current research and future considerations. Psychiatric Rehabilitation Journal, 34(3), 252-254. doi: 10.2975/34.3.2011.252.254

Newsom, J. T., \& Schulz, R. (1996). Social support as a mediator in the relation between functional status and quality of life in older adults. Psychology and Aging, 11(1), 34-44. doi: 10.1037//0882-7974.11.1.34

Nurosis, M. (1993). SPSS. Statistical data analysis. New York: SPSS Inc.

O’Reailly, P. (1988). Methodological issues in social support and social network research. Social Science Medicine, 26(8), 863-873.

Ownsworth, T., Henderson, L., \& Chambers, S. K. (2010). Social support buffers the impact of functional impairments on caregiver psychological well-being in the context of brain tumor and other cancers. PsychoOncology 19(10), 1116-1122. doi: 10.1002/pon.1663

Pardo, A., \& Ruiz. SPSS 11: Guia para el análisis de datos [SPSS 11: A guide for data analysis]. Madrid: McGraw-Hill.

Perrin, K. M., \& McDermott, R. J. (1997). Instruments to Measure Social Support and Related Constructs in Pregnant Adolescents: A Review. Adolescence, 32(4), 533-557. Retrieved from: http://www.journals.elsevier.com/journal-of-adolescence/

Phillips, D. R., Siu, O. L., Yen, A. G., \& Cheng, K. H. (2008). Informal social support and older persons' psychological well-being in Hong Kong. Journal of Cross-Cultural Gerontology, 23(1), 39-55. doi: 10.1007/s10823007-9056-0

Pons-Salvador, G., Cerezo, M. A., \& Trenado, R. M. (2014). Efecto de la dosis de intervención del Programa de Apoyo Psicológico P/Materno Infantil sobre las madres y sus bebes. [Dose-effect on the mothers and babies attending the Programa de Apoyo Psicológico P/MaternoInfantill. Anales de Psicología, 30(2), 474-481. doi: 10.6018/analesps.30.2.141192

Procidano, M. E. (1983). Measures of perceived social support from friends and from family: three validation studies. American Journal of Community Psychology, 11(1), 1-24. doi: 10.1007/BF00898416

Rimé, B., Páez, D., Basabe, N., \& Martínez, F. (2010). Social sharing of emotion, post-traumatic growth, and emotional climate: Follow-up of Spanish citizen's response to the collective trauma of March 11th terrorist attacks in Madrid. European Journal of Social Psychology, 40(6), 10291045. doi: 10.1002/ejsp.700

Rivas-Díez, R. (2013). Functional social support in the general population and Chilean battered women. Psychometric properties of the DukeUNC-11. Revista Iberoamericana de Diagnóstico y Evaluación, 36(2), 9-27.

Salovey, P., Rothman, A. J., Detweiler, J. B., \& Steward, W. T. (2000). Emotional states and physical health. American Psychologist, 55(1), 110121. doi: 10.1037//0003-066X.55.1.110

Sarason, B. R., Levine, H. M., Basham, R. B., \& Sarason, I. G. (1983). Assessing Social Support: The Social Support Questionnaire. Journal of Personality and Social Psychology, 44, 127-139.

Sarason, B. R., Sarason, I. G., \& Pierce, G. G. (1990). Social support: An interactional view. New York: John Wiley.

Shakespeare-Finch, J., \& Obst, P. L. (2011). The development of the 2-way social support scale: A measure of giving and receiving emotional and instrumental support. Journal of Personality Assessment, 93(5), 483-490. doi: 10.1080/00223891.2011.594124
Sherbourne, C. D., \& Stewart, A. L. (1991). The MOS social support survey. Social Science \& Medicine, 32, 705-714. doi: 10.1016/02779536(91)90150-B

Sherman, A. M., Skrzypek, A., Bell, R., Tatum, C., \& Paskett, E. D. (2011). The contribution of social support and social strain to depressive symptoms in African American, native American, and European American women. Journal of Social and Personal Relationships, 28(8), 1104-1129. doi: 10.1177/0265407511406895

Song, J. I., Shin, D. W., Choi, J. Y., Kang, J., Baik, Y. J., Mo, H., \& Park, M. H. (2011). Quality of life and mental health in family caregivers of patients with terminal cancer. Supportive Care in Cancer 19(10), 1519-1526. doi: 10.1007/s00520-010-0977-8

Tardy, C. H. (1985). Social Support Measurement. American Journal of Community Psychology, 13(2), 187-202. doi: 10.1007/BF00905728

Taylor, S. E., \& Brown, J. D. (1988). Illusion and Well-Being: A Social Psychological Perspective on Mental Health. Psychological Bulletin, 103(2), 193-210. doi: 10.1037//0033-2909.103.2.193

Terol, M. C., López, S., Neipp, M.C., Rodríguez, J., Pastor, M. A., \& Martín-Aragón, M. (2004). Apoyo social e instrumentos de evaluación: revisión y clasificación. [Social Support and Assessment Instruments: A Revision and Clasification]. Anuario de Psicología, 35(1), 23-45. Retrieved from: http://www.ub.edu/psicologia/castellano/anuario-de-psicologia

Umaña-Taylor, A. J., Updegraff, K. A., White, R. M., Herzog, M. J., Pflieger, J. C., \& Madden-Derdich, D. (2011). Developing and Testing a Measure of Social Support With Mexican-Origin Pregnant Adolescents and Their Mother Figures. Hispanic Journal of Behavioral Sciences, 33(3), 377-397. doi: 10.1177/0739986311412930

Vangelisti, A. L. (2009). Challenges in conceptualizing social support. Journal of Social and Personal Relationships, 26(1), 39-51. doi: 10.1177/0265407509105520

Vaux, A. (1988). Social Support: Theory, Research and Intervention. New York: Praeger.

Vaux, A. (1992). Assessment and analysis. En H. Veiel \& U. Baumann (Eds.), The meaning and measurement of social support (pp. 193-216). New York: Hemisphere.

Veiel, H. O. (1987). The Manheim Interview on Social Support. Manheim: Central Institute of Mental Health.

Warner, R. M. (2008). Applied statistics: From bivariate through multivariate techniques. Thousand Oaks: Sage Publications Inc.

Weiss, R. S. (1973). Loneliness: The experience of emotional and social isolation. Cambridge, Mass: MIT Press

Winemiller, D. R., Mitchell, M. E., Sutliff, J., \& Cline, D. J. (1993). Measurement strategies in social support: a descriptive review of the literature. Journal of Clinical Psychology, 49(5), 638-648. doi: 10.1002/10974679(199309)49:5<638::AID-JCLP2270490505>3.0.CO;2-7

Yárnoz, S. (2008). Adaptación al castellano de la Escala para la Evaluación de la Soledad Social y Emocional en Adultos SESLA-S [Spanish Adaptation of the Scale for the Assessment of Social and Emotional Loneliness in Adults SESLA-S]. International Journal of Psychology and Psychological Therapy, 8(1), 103-116. Retrieved from: http:/ / www.redalyc.org/articulo.oa?id $=56080109$

Zimet, G. D., Dahlem, N. W., Zimet, S. G., \& Farley, G. K. (2010). The Multidimensional Scale of Perceived Social Support. Journal of Personality Assessment, 52(1), 30-41. doi: 10.1207/s15327752jpa5201_2

(Article received: 06-07-2014; revised: 28-12-2014; accepted: 08-04-2015) 
Appendix - QFSSS (English version)

Questionnaire on the frequency of and satisfaction with social support (QFSSS).

Indicates the frequency of and satisfaction with support received from your partner, family, friends, and the community

\section{HOW OFTEN DO YOUHOW SATISFIED ARE RECEIVE SUPPORT? YOU WITH THE SUP- PORT RECEIVED?}

PARTNER

1. Rarely

1. Dissatisfied

2. Sometimes

2. Barely satisfied

3. Quite often

3. Fairly satisfied

4. Almost always

4. Quite satisfied

5. Always

5. Very satisfied

EMOTIONAL SUPPORT: your partner is loving, affectionate and FREQUENCY SATISFACTION

listens to you when you want to talk and express your feelings.

INSTRUMENTAL SUPPORT: Would do you a favour if needed or is willing to do specific things for you, such as providing money, taking you to the doctor or helping you in any other activity

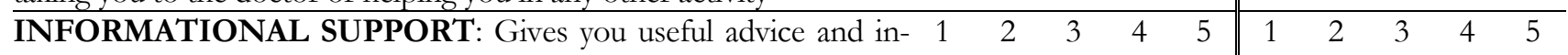
formation regarding questions, problems or daily tasks

FAMILY FREQUENCY

EMOTIONAL SUPPORT: They are loving and affectionate and 1 listen to you when you want to talk and express your feelings.

INSTRUMENTAL SUPPORT: Would do you a favour if needed 1 \begin{tabular}{llllll|llllll} 
& 2 & 3 & 4 & 5 & 1 & 2 & 3 & 4
\end{tabular} or are willing to do specific things for you, such as providing money, taking you to the doctor or helping you in any other activity

INFORMATIONAL SUPPORT: Give you useful advice and in- 1 \begin{tabular}{lllll|lllll} 
& 2 & 3 & 4 & 5 & 1 & 2 & 3 & 4
\end{tabular} formation regarding questions, problems or daily tasks

\begin{tabular}{|c|c|c|c|c|c|c|c|c|c|c|}
\hline FRIENDS & FRI & QL & $\mathbf{N}$ & & & SA] & & & $\mathrm{ON}$ & \\
\hline $\begin{array}{l}\text { EMOTIONAL SUPPORT: they are loving and affectionate and lis- } \\
\text { ten to you when you want to talk and express your feelings. }\end{array}$ & 1 & 2 & 3 & 4 & 5 & 1 & 2 & 3 & 4 & 5 \\
\hline $\begin{array}{l}\text { INSTRUMENTAL SUPPORT: Would do you a favour if needed } \\
\text { or are willing to do specific things for you, such as providing money, } \\
\text { taking you to the doctor or helping you in any other activity }\end{array}$ & 1 & 2 & 3 & 4 & 5 & 1 & 2 & 3 & 4 & 5 \\
\hline $\begin{array}{l}\text { INFORMATIONAL SUPPORT: Give you useful advice and in- } \\
\text { formation regarding questions, problems or daily task }\end{array}$ & 1 & 2 & 3 & 4 & 5 & 1 & 2 & 3 & 4 & 5 \\
\hline $\begin{array}{l}\text { COMMUNITY (support from neighbours, the parish, associations } \\
\text { and clubs, and the community in general) }\end{array}$ & & $\mathbf{R I}$ & $2 \mathbf{U}$ & NC & & & T] & $\mathrm{A}$ & ГIC & \\
\hline $\begin{array}{l}\text { EMOTIONAL SUPPORT: they are loving and affectionate and lis- } \\
\text { ten to you when you want to talk and express your feelings. }\end{array}$ & 1 & 2 & 3 & 4 & 5 & 1 & 2 & 3 & 4 & 5 \\
\hline $\begin{array}{l}\text { INSTRUMENTAL SUPPORT: Would do you a favour if needed } \\
\text { or are willing to do specific things for you such as providing money, } \\
\text { taking you to the doctor or helping you in any other activity }\end{array}$ & & 2 & 3 & 4 & 5 & 1 & 2 & 3 & 4 & 5 \\
\hline $\begin{array}{l}\text { INFORMATIONAL SUPPORT: Give you useful advice and in- } \\
\text { formation regarding questions, problems or daily tasks }\end{array}$ & & 2 & 3 & 4 & 5 & 1 & 2 & 3 & 4 & 5 \\
\hline
\end{tabular}


Appendix CFSAS (Spanish version)

Cuestionario de frecuencia y satisfacción con el apoyo social (QFSAS).

Indique la frecuencia y satisfacción con el apoyo recibido de su pareja,

familia, amigos, y comunidad.

$\begin{array}{lclr}\text { ¿CON } & \text { QUÉ } & \text { ¿CÓMO } & \text { ESTÁ } \\ \text { FRECUENCIA } & \text { DE } & \text { SATISFE- } \\ \text { RECIBE } & \text { APO- } & \text { CHO CON } & \text { CA- } \\ \text { YO? } & \text { DA TIPO } & \text { DE } \\ & & \text { APOYO? }\end{array}$

1. Rara vez

1. Insatisfecho

2. A veces

2. Poco satisfe-

3. Bastante a me- cho

nudo 3. Algo satisfecho

4. Casi siempre 4. Bastante satis-

5. Siempre fecho

PAREJA

APOYO EMOCIONAL: Por ejemplo, te da cariño, afecto o te escucha cuan- \begin{tabular}{cccccc||ccccc} 
& 1 & 2 & 3 & 4 & 5 & 1 & 2 & 3 & 4 & 5
\end{tabular} do quieres hablar y expresar tus sentimientos.

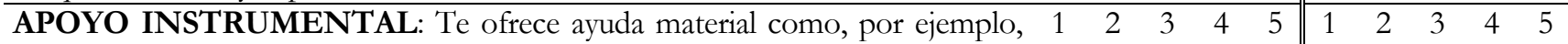
dinero que necesitas, te acompaña para ir a algún sitio, etc.

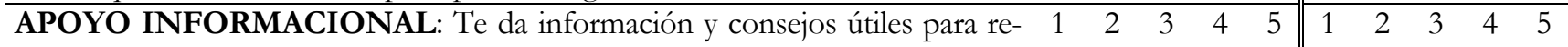
solver, por ejemplo, tus dudas o las cosas que debes hacer a diario

FAMILIA FREQUENCIA SATISFACCIÓN

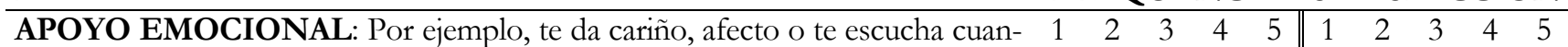
do quieres hablar y expresar tus sentimientos.

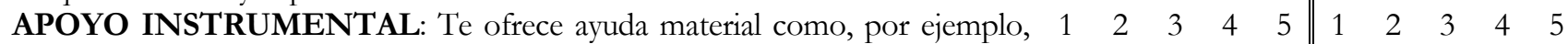
dinero que necesitas, te acompaña para ir a algún sitio, etc.

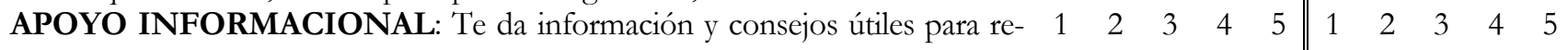
solver, por ejemplo, tus dudas o las cosas que debes hacer a diario

AMIGOS FREQUENCIA SATISFACCIÓN

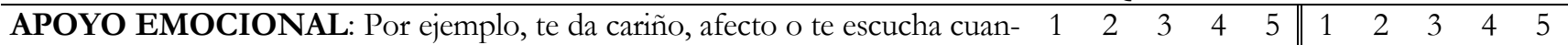
do quieres hablar y expresar tus sentimientos.

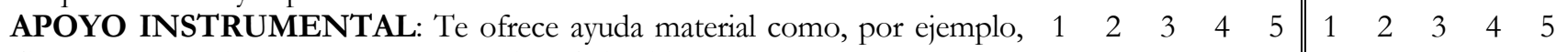
dinero que necesitas, te acompaña para ir a algún sitio, etc.

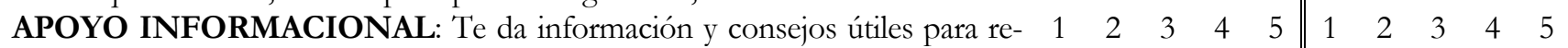
solver, por ejemplo, tus dudas o las cosas que debes hacer a diario

COMUNIDAD (apoyo procedente de vecinos, parroquia, asociaciones y pe-

ñas, y de la comunidad en general).

FREQUENCIA SATISFACCIÓN

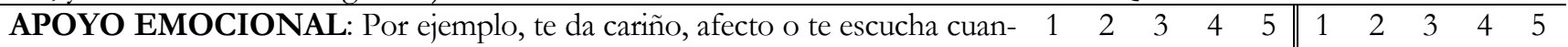
do quieres hablar y expresar tus sentimientos.

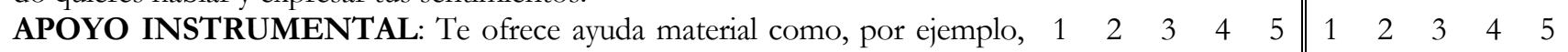
dinero que necesitas, te acompaña para ir a algún sitio, etc.

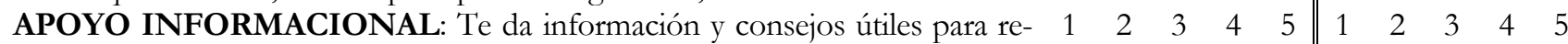
solver, por ejemplo, tus dudas o las cosas que debes hacer a diario 